\title{
Virus diseases of berry plants in Finland
}

\author{
KATRI BREMER \\ Department of Plant Pathology, University of Helsinki \\ SF-00710 Helsinki, Finland
}

\begin{abstract}
Virus diseases of berry plants became more common and harmful in the 1960s, when berry cultivation expanded in Finland.

Virus diseases seldom occur in strawberry because the main vector, Chaetosiphon fragaefolii, does not thrive in Finland. However NEPO-viruses are found in Finland in plant nurseries and in berry cultivations, and they may become a danger for strawberry as well as for raspberry growing. Both wild and cultivated raspberries are commonly infected by viruses. The vector aphids also occur in Finland. Reversion disease infects black currants. The veinbanding virus disease is common in red currants and gooseberries.

Virus diseases of berries are poorely investigated in Finland. The healthy plant propagation and certification scheme was established in the 1970s. More research is needed in order to understand our virus problems, to develop proper test methods, and to prevent virus spread.
\end{abstract}

Index words: berry plants, virus diseases

\section{Introduction}

Virus diseases of berry plants were nearly unknown in Finland until the 1970s. Only an epidemic-like occurrence and first spread over the whole country of a vector, the gall mite (Eriophyes ribis) had been described earlier (HuKKINEN 1923). As a result of a change in agricultural policy in the $1960 \mathrm{~s}$, farmers began to specialize and cultivate unconventional plants. Particularly farmers in central and eastern Finland had to find crops suitable for their small hill-side fields that would also help them avoid competition with the cereal growers in southern Finland. At the same time, the general market situation was favourable for berry cultivation because dairy industry began to use more berries and fruit in their products, e.g. yoghurts.

Strawberry cultivation area increased from 953 ha in 1973 to 2825 ha in 1983 (YeARBOOK Of Farm Statistics 1983). The area of black currant, the second important berry, has not increased recently, but many black currant fields were replanted in the 1970 s, partly as a attempt to control mildew (Sphaerotheca ribis) by using a more resistant cultivar than before. 
Originally berries were cultivated in small home gardens scattered all over the country, which naturally hindered outbreaks of epidemics. Thus many diseases, particularly virus diseases, remained unnoticed and unrecognized. Fungal diseases were known earlier, and their control by fungicides was adviced to farmers. The rapid increase in commercial berry growing also increased the demand for propagation material. In this situation plant nurseries failed to keep the quality of planting material high enough, and lots of ungenuine and diseased plants were produced and sold. At the beginning of the 1970 s, a committee was called to plan the production of healthy and genuine propagation material of berry plants, and tests to index their virus diseases were carried out. In 1976, the healthy plant propagation programme was confirmed and settled by law, and a station to maintain and propagate healthy and genuine planting material was founded (BREMER and YLIMÄKI 1978).

\section{Virus diseases of strawberry}

54 virus diseases and 8 mycoplasma diseases are known to infect strawberry in the world (AERTs 1974). Harmful virus diseases can be divided into two groups according to their vectors: aphid-transmitted and nematode- transmitted diseases (Tables 1 and 2). Strawberry aphid, Chaetosiphon fragaefolii and other Chaetosiphon sp., transmit several viruses of strawberry, the most common in Europe being strawberry crinkle, strawberry mottle, strawberry veinbanding, and strawberry mild yellow edge. Only the first two have been described in detail (MAAs 1984). Aphidborne virus diseases have caused severe yield losses in central and southern Europe (AERTS 1974, Babovic 1976). However, none of the Chaetosiphon aphids occurs in Finland because of the cold climate. Even in northern Germany, cold winters restrict the propagation and spread of $C$. fragaefolii, the aphids often die before the latent period of the virus is completed (KRCAL 1980). Some other aphids capable of transmitting strawberry viruses occur in Finland, but they are inefficient vectors (MAAS 1984). Thus aphid transmissible viruses spread in Finland mainly by the help of man through vegetative propagation material. Further, sources of infection also seem to be scarce. The author tested wild strawberries (Fragaria vesca) collected from field borders and forests, and none of them was virus infected. According to similar tests, about $12 \%$ of the plants in strawberry fields were virus infected before tested healthy plants were used (BREMER and PethMAN 1978). Part of the planting material was

Table 1. Strawberry virus diseases.

\begin{tabular}{|c|c|c|c|c|c|c|}
\hline \multirow[t]{2}{*}{ Disease } & \multirow[t]{2}{*}{ Cryptogram } & \multirow[t]{2}{*}{ Virus group } & \multicolumn{2}{|c|}{ Transmission by } & \multicolumn{2}{|c|}{ Distribution } \\
\hline & & & Vector & Sap & & $\begin{array}{l}\text { In } \\
\text { Finland }\end{array}$ \\
\hline 1) Strawberry mottle & $\cdots$ & $\cdots$ & $\begin{array}{l}\text { Chaetosiphon } \\
\text { sp.p. }\end{array}$ & $+?$ & World wide & + \\
\hline 2) Strawberry crinkle & ${ }^{*} /{ }^{*} ;{ }^{*} / *^{*}: \mathrm{u} / \mathrm{E}: \mathrm{S}, 1 / \mathrm{Ap}$ & Rhabdovirus & $n$ & - & $\begin{array}{l}\text { In Europe, } \\
\text { USA }\end{array}$ & + \\
\hline 3) Strawberry veinbanding & ${ }^{*} / * ; * / *: \mathrm{S} / \mathrm{S}: \mathrm{S} / \mathrm{Ve} / \mathrm{Ap}$ & Caulimovirus & $\begin{array}{l}\text { " } \\
+ \text { Amphomorpha } \\
\text { and Myzus sp.p. }\end{array}$ & + & $n$ & $+?$ \\
\hline $\begin{array}{l}\text { Strawberry mild } \\
\text { yellow edge }\end{array}$ & $\cdots$ & Luteovirus & $\begin{array}{l}\text { Chaetosiphon } \\
\text { sp.p. }\end{array}$ & - & World wide & $+?$ \\
\hline
\end{tabular}

1) Sylvester et al. (1976)

2) Frazier \& Converse (1980)

3) Maas (1984) 
Table 2. NEPO-viruses in berry plants.

\begin{tabular}{|c|c|c|c|c|c|c|c|}
\hline \multirow{2}{*}{$\begin{array}{l}\text { Virus } \\
\\
\begin{array}{l}\text { Arabis mosaic } \\
\text { virus }\end{array}\end{array}$} & \multirow{2}{*}{$\begin{array}{l}\text { Cryptogram } \\
\text { R/I:*/41:S/S:S/Ne }\end{array}$} & \multirow{2}{*}{$\begin{array}{l}\text { Host } \\
\begin{array}{l}\text { Strawberry, } \\
\text { raspberry, } \\
\text { currants }\end{array}\end{array}$} & \multirow{2}{*}{$\begin{array}{l}\text { Vector } \\
\\
\text { Xiphihema } \\
\text { diversicaudatum, } \\
\text { X. index }\end{array}$} & \multicolumn{2}{|l|}{ Other means } & \multicolumn{2}{|c|}{$\begin{array}{c}\text { Distribution } \\
\text { of } \\
\text { the vector } \\
\text { the virus } \\
\text { in Finland }\end{array}$} \\
\hline & & & & $\begin{array}{l}\text { Sap, seed } \\
\text { pollen }\end{array}$ & In Europe & - & + \\
\hline $\begin{array}{l}\text { Raspberry ring } \\
\text { spot }\end{array}$ & $\begin{array}{l}\mathrm{R} / 1:(2,4 / 43)+ \\
(1,4 / 30) \\
\text { OR } 2 \times 1,4 /(46: S) \\
\text { S/S:S/C, } \mathrm{Ve} / \mathrm{Ne}\end{array}$ & $\begin{array}{l}\text { Strawberry, } \\
\text { raspberry, } \\
\text { currants }\end{array}$ & $\begin{array}{l}\text { Longidorus } \\
\text { elongatus, } \\
\text { L. macrosoma }\end{array}$ & $\begin{array}{l}\text { Sap, seed } \\
\text { pollen }\end{array}$ & $n$ & $\begin{array}{l}+ \\
+\end{array}$ & - \\
\hline $\begin{array}{l}\text { Tomato black } \\
\text { ring }\end{array}$ & $\begin{array}{l}\mathrm{R} /{ }^{*}: * / 38: \mathrm{S} / \mathrm{S}: \mathrm{S} / \mathrm{Ne} \\
\mathrm{R} / \mathrm{I}: 2,5+1,5\end{array}$ & $\begin{array}{l}\text { Strawberry, } \\
\text { currants }\end{array}$ & $\begin{array}{l}\text { L. elongatus } \\
\text { L. attenuatus }\end{array}$ & $\begin{array}{l}\text { Sap, seed, } \\
\text { pollen }\end{array}$ & $"$ & + & + \\
\hline $\begin{array}{l}\text { Strawberry latent } \\
\text { ring spot }\end{array}$ & $\begin{array}{l}\mathrm{R} / 1: 2,6 \\
2 \times 1,6 / 38: \mathrm{S} / \mathrm{S}: \mathrm{S} / \mathrm{Ne}\end{array}$ & $\begin{array}{l}\text { Strawberry, } \\
\text { black \& red } \\
\text { currant, } \\
\text { raspberry }\end{array}$ & $\begin{array}{l}\text { X. diversi- } \\
\text { caudatum } \\
\text { X. coxi }\end{array}$ & $\begin{array}{l}\text { Sap, seed, } \\
\text { pollen }\end{array}$ & $"$ & $\begin{array}{l}- \\
- \\
-\end{array}$ & + \\
\hline $\begin{array}{l}\text { Tobacco ring } \\
\text { spot }\end{array}$ & $\begin{array}{l}\mathrm{R} / 1: 2,2 / 40: \\
\mathrm{S} / \mathrm{S}: \mathrm{S} / \mathrm{Ne}\end{array}$ & $\begin{array}{l}\text { Strawberry, } \\
\text { raspberry, } \\
\text { currants }\end{array}$ & X. americanum & Sap, seed & $\begin{array}{l}\text { USA, some } \\
\text { European } \\
\text { countries }\end{array}$ & - & - \\
\hline $\begin{array}{l}\text { Tomato ring } \\
\text { spot }\end{array}$ & $\begin{array}{l}\mathrm{R} / 1: 2,3 / 40: \\
\mathrm{S} / \mathrm{S}: \mathrm{S} / \mathrm{Ne}\end{array}$ & Raspberry & X. americanum & Sap, seed & $\begin{array}{l}\text { USA, in im- } \\
\text { ported plants } \\
\text { in Europe }\end{array}$ & - & - \\
\hline
\end{tabular}

imported. It seems that aphid transmissible virus diseases spread to Finland only in imported planting material, and the use of tested plants controls them effectively.

\section{NEPO-virus diseases}

NEPO-viruses, Arabis mosaic, raspberry romg spot, tomato black ring, and strawberry latent ring spot, cause severe damage to strawberries in many countries, the first three being most destructive (Table 3 ). All these viruses have been found in Finland in plant nurseries and in the field (TAPIO 1972, 1985, BREMER 1985), but it is not known how common they are or whether they are a potential danger to strawberry cultivation in Finland. NEPOviruses also infect raspberry and currants, and they are especially harmful to raspberry.

All NEPO-viruses have similar properties, but they are distinctly different viruses. They contain bipartite single-strand RNA genomes, which are encapsidated separately but have identical protein coats (HARrISON and Mu-
RANT 1977). Both parts are necessary for infection. NEPO-viruses are transmitted by nematodes Xiphinema and Longidorus sp. via sap, seed, and pollen (Harrison and Murant 1977). Xiphinema nematodes have not been found in Finland, though Arabis mosaic and strawberry latent ring spot viruses, which are transmitted by them (TAYLOR and THOMAS 1968), occur in Finnish plant nurseries (TAPIO 1972, 1985). They have probably been imported to Finland in foreign propagation material. The only means they can spread here in nature is via seed or pollen. Arabis mosaic is transmitted via seed of several weeds, strawberry, and raspberry. Pollen transmission by weeds and strawberry is also known (LISTER and Murant 1967).

Berry plants are not propagated by seed except in breeding. Thus seed transmission of the viruses that have no vector in Finland, is not important. Pollen transmission, if it causes infection in the mother plant, can be very destructive in the production of virus tested plants. In one experiment, healthy 
strawberry mother plants were pollinated by pollen containing raspberry ring spot virus, but no plants became infected. Infected pollen competed poorly with virus-free pollen (Lister and Murant 1967). However, raspberry bushy dwarf virus is naturally transmitted via pollen, and plants get infected $(\mathrm{Mu}$ RANT et al. 1974).

At present several tested strawberry cultivars are available in Finland. On average, they have yielded $59 \%$ more than untested plants in experimental fields (Kallio et al. 1980). At the same time yields in farmers' fields have increased, on average $1000 \mathrm{~kg} / \mathrm{ha}$ (AssociAtion Of Berry Growers, oral comm.). However, most of this increase may be due to the eradication of mites and leaf nematodes.

\section{Virus diseases of raspberry}

Red raspberry (Rubus idaeus) is not largely grown in Finland, and its area has decreased from about 168 ha in 1973 to 92 ha in 1983 (Yearbook Of Farm Statistics 1983). Black raspberry ( $R$. occidentalis) is only grown in home gardens. Recently, however, raspberry cultivation has aroused more interest, and some fields have been planted. Experiments on suitable cultivation and harvesting methods, including the control of pests and cane diseases, are in progress.

Wild raspberries are common in Finland. They often show symptoms of virus diseases (JAMALAINEN 1957) as well as virus-like yellow fleck symptoms caused by the mite Eriophyes gracilis (Lindroth (LiRo) 1902). According to TAPIO (1961), several virus diseases occur in Finland, e.g. red raspberry mosaic, raspberry vein chlorosis, raspberry vein banding, raspberry yellows, raspberry leaf mottle, and raspberry leaf curl, but they have not been described in more detail. A mycoplasma disease, Rubus stunt, has also been found in Finland.

More than twenty viruses infecting raspberry have been found in Europe, but not all of them are significant, and some are still poorly described. Some virus diseases transmitted by aphids or nematodes have caused severe yield losses (FreEman and STACE-SMith 1970, BaUMANn 1984, 1986). Raspberry viruses often occur together in the same plant. Thus

Table 3. Virus diseases of raspberry (Rubus idaeus) occurring in Europe.

\begin{tabular}{|c|c|c|c|c|c|c|c|}
\hline \multirow[t]{2}{*}{ Disease and virus } & \multirow[t]{2}{*}{ Cryptogram } & \multirow[t]{2}{*}{ Virus group } & \multirow[t]{2}{*}{ Distribution } & \multirow[b]{2}{*}{ Vector } & \multicolumn{3}{|c|}{ Transmission by } \\
\hline & & & & & sap & seed & pollen \\
\hline $\begin{array}{l}\text { 1) Raspberry bushy } \\
\text { dwarf }\end{array}$ & $\begin{array}{l}\mathrm{R} / 1:(2.0+0.8+0.3) \\
/(24): \mathrm{S} / \mathrm{S}: \mathrm{S} / \mathrm{O}\end{array}$ & $\begin{array}{l}\text { Possible ilar } \\
\text { virus }\end{array}$ & $\begin{array}{l}\text { In some cvs. } \\
\text { world wide }\end{array}$ & $\cdots$ & $\begin{array}{l}+ \\
+\end{array}$ & + & + \\
\hline $\begin{array}{l}\text { Heat labile viruses: } \\
\text { Raspberry leaf } \\
\text { mottle }\end{array}$ & $\begin{array}{l}\text { Not enough charac- } \\
\text { terised }\end{array}$ & $?$ & $\begin{array}{l}\text { Common in } \\
\text { Europe }\end{array}$ & $\begin{array}{l}\text { Amphoropha } \\
\text { rubi }\end{array}$ & - & - & - \\
\hline $\begin{array}{l}\text { Raspberry leaf } \\
\text { spot }\end{array}$ & $n$ & $?$ & $m$ & " & - & - & - \\
\hline $\begin{array}{l}\text { Black raspberry } \\
\text { necrosis }\end{array}$ & $"$ & $?$ & $n$ & $"$ & + & - & - \\
\hline $\begin{array}{l}\text { Heat stabile viruses: } \\
\text { 2) Raspberry vein } \\
\text { chlorosis }\end{array}$ & $\begin{array}{l}* /:^{*} /{ }^{*}: \mathrm{Ue} / \mathrm{E}: \mathrm{S} \\
/ \mathrm{Ve} / \mathrm{As}\end{array}$ & Rhabdovirus & $\begin{array}{c}\text { " } \\
+ \text { in USA, } \\
\text { Canada }\end{array}$ & Aphis idaei & - & - & - \\
\hline $\begin{array}{l}\text { 3) Rubus yellow } \\
\text { net }\end{array}$ & $\begin{array}{l}* / *: * / *: \mathrm{U} / *: \mathrm{S} \\
/ \mathrm{Ve} / \mathrm{Ap}\end{array}$ & $\begin{array}{l}\text { A possible } \\
\text { cacao swollen } \\
\text { shoot virus }\end{array}$ & $m$ & $\begin{array}{l}\text { Amphoropha } \\
\text { rubi }\end{array}$ & - & - & - \\
\hline
\end{tabular}

1) Murant 1976

2) Jones et al. 1977

3) R. Stace-Smith \& Jones 1978 
raspberry mosaic is caused by several viruses (Table 3), and symptoms vary according to the combination of infecting viruses.

The testing and production of virus-free raspberries by heat treatment was started in the early $1960 \mathrm{~s}$ on the initiative of TAPIO. Virus tested raspberries have performed well. For example, the yield of cultivar Preussen in a field experiment was $8000-6000 \mathrm{~kg} / \mathrm{ha}$ during five years compared to 530-1200 $\mathrm{kg} / \mathrm{ha}$ of untested, normal plants of the same age (BREMER 1980). At present virus tested planting material of three cultivars is available.

\section{Virus diseases of currants and gooseberries}

Several virus diseases of currants have been found in Finland (Table 4) but none of them is well characterized, and they have been identified mainly on the basis of their symptoms in host and test plants.

The reversion disease, the causal agent of which is unknown, can be very harmful to black currants, and several strains are known. The severe strain, which causes deformations and sterility of flowers, is rare in Finland. The weaker strains have also become rare after virus tested plants became commonly used.
The veinbanding virus disease and its aphid vectors are very common in red currant and gooseberry. Infectious variegation and some viruslike diseases have been found in some currant fields (BREMER 1983).

Same NEPO-viruses infect both currants and strawberry. In Finland, raspberry ring spot and tomato black ring are found in black currants (BREMER 1983). They do not seem to be harmful to the plants but may be spread and preserved with them.

\section{Other berries}

Nordic bramble, Rubus arcticus, and its hybrids with $R$. stellatus are grown on a small scale for berry industry. A sap transmissible, unidentified virus causing yellow mosaic on the leaves of Nordic brambles has been found (BREMER 1985).

Aronia melanocarpa cv. Viking is cultivated for berry production. A virus, causing ring spot symptoms on the leaves and having isometric particles, has been found. The disease does not seem to spread (BREMER 1984).

A mycoplasma disease causing withces' broom symptoms occurs in blueberries (Vaccinium myrtillus) and red bilberries (V. vitisidaea) in forests, and it has probably been in Finland for a long time (BREMER 1981).

Table 4. Virus diseases of currants and gooseberry.

\begin{tabular}{|c|c|c|c|c|c|}
\hline Disease & Causal agent & Vector & $\begin{array}{c}\text { Sap } \\
\text { transmission }\end{array}$ & $\begin{array}{l}\text { Distribution } \\
\text { abroad and } \\
\text { in Finland }\end{array}$ & Importance \\
\hline $\begin{array}{l}\text { Reversion of } \\
\text { black currant }\end{array}$ & Unknown & $\begin{array}{l}\text { Mite, Erio- } \\
\text { phyes ribis }\end{array}$ & - & Common & +++ \\
\hline $\begin{array}{l}\text { Veinbanding of } \\
\text { gooseberry }\end{array}$ & $\begin{array}{l}\text { Probably } \\
\text { virus }\end{array}$ & $\begin{array}{l}\text { Several } \\
\text { aphid sp.p. }\end{array}$ & - & $"$ & ++ \\
\hline $\begin{array}{l}\text { Veinbanding of } \\
\text { red currant }\end{array}$ & $"$ & $"$ & - & $"$ & ++ \\
\hline $\begin{array}{l}\text { Infectious varie- } \\
\text { gation of currants }\end{array}$ & $"$ & Unknown & - & Rare & - \\
\hline $\begin{array}{l}\text { Cucumber mosaic } \\
\text { virus }\end{array}$ & $\begin{array}{l}\mathrm{R} / 1: 1 / 18: \mathrm{S} \\
/ \mathrm{S}: \mathrm{S} / \mathrm{Ap}\end{array}$ & Aphids & + & $\begin{array}{l}\text { Seldom in } \\
\text { Ribes, com- } \\
\text { mon in other } \\
\text { plants }\end{array}$ & - \\
\hline
\end{tabular}




\section{Discussion}

Virus diseases of berry plants are not a serious problem in Finland, mainly because the cold climate restricts vectors, and there are probably not many virus sources.

Wild strawberries seem to be free of viruses, and about $90 \%$ of commercial strawberry farmers now use tested healthy plants for founding their fields.

In contrast to strawberry, wild raspberries and raspberries in home gardens are often virus-infected. Aphid vectors Aphis idaei and Amphorophora rubi, which transmit several viruses, are common in Finland (HEIKINHEIMO 1956).

Reversion disease occurs in black currants and occasionally in wild Ribes alpinum. The vector, E. ribis, occurs all over Finland, though to a lesser extent in the north. The use of tested planting material has diminished the occurrence of the vector and disease.

NEPO-viruses occur in berry plants and in plant nurseries, where they are harmful to many perennial ornamental plants. NEPOand other soil-borne viruses might become a problem in the future because they persist in soil and infect nursery plants. Thus there is a consistent danger of their spreading into new areas.

More research should be done on soil-borne viruses, on collecting and comparing isolates and characterizing them. To get quick and reliable test methods, suitable immunological tests and practical applications of nucleic acid analysis and DNA hybridization for large scale tests should be developed. Further, be- cause of our short summer, there is an increasing interest amont nurseries in propagating plants through tissue culture. The first commercial laboratory already exists. New cultivars are propagated through tissue culture and should also be tested. Tissue culture propagation is a very effective way of spreading plant diseases if careful inspection and testing are neglected.

Another subject worth while examining would be virus and virus-like diseases of currants and gooseberry. They are as a whole poorly investigated. The etiology of the reversion disease is not known. A potyvirus, a bacterium (JАСOB 1976), and a mycoplasma (SILVERE 1970) have been suggested as causes of this disease. The agent of the veinbanding disease of red currant and gooseberry is also unknown, though the disease causes yield losses (Thresh 1970).

A good knowledge of our viruses is necessary for developing proper test methods and for preventing virus spread into fields. It is vitally important for resistance breeding, too. Resistance against some viruses has been found in red raspberry. Inserting viral DNA copies into plants has opened new possibilities for getting virus tolerant and resistant plants. (HARrison et al. 1987). The necessity of a quarantine station (jointed into an existing plant protection institute) for nontested perennial plants, such as bushes and trees, should be taken into consideration. Plant quarantine inspection should include plant nurseries and new cultivars of perennial plants bred in Finland.

\section{References}

Aerts, J. 1974. Survey of viruses and mycoplasmas in strawberry. Neth. J. Plant Path. 80: 215-217.

BABovic, M. V. 1976. Changes in the yield and quality of strawberry fruits infected by strawberry crinkle virus. Acta Horticulturae. 66: 25-28.

Baumann, G. 1984. Virusbefall in Entrags- und Vermehrungsbeständen von Himbeere und Brombeere. I Blattlaus übertragbare Viren. Erwerbsobstblau 26: 188 -192 .

- 1986. The influence of heat-labile viruses of raspberry common mosaic on growth and cropping of red raspberry. Acta Horticulturae 186: 39-46.

Bremer, K. \& Pethman, M. 1978. Occurrance of virus diseases in Finnish strawberries. Ann. Agric. Fenn. 17: $38-41$.

Bremer, K. \& Ylimákı, A. 1978. A certificate system to produce and distribute virus tested propagation material 
from berry plants in Finland. Ann. Agric. Fenn. 17: $42-44$.

Bremer, K. 1980. Hyviä satoja vadelman terveillă taimilla. Puutarha. 83: 526-527.

- 1981. Witches' broom disease of Arctostaphylos and Vaccinium species in Finland. Ann. Agric. Fenn. 20: 188-191.

- 1983. Viral diseases occurring in Ribes species in Finland. Ann. Agric. Fenn. 22: 104-109.

- 1984. Ring spot of Aronia melanocarpa, a disease caused by an isometric virus transmissible via sap and seed. Ann. Agric. Fenn. 23: 176-182.

- 1985. Strawberry latent ring spot virus in ornamental plants in Finland. Ann. Agric. Fenn. 24: 101-102.

Frazier, N. W. \& Converse, R. H. 1980. Strawberry vein banding virus. Commonw. Mycol. Inst. Assoc. Appl. Biol. Descript. of Plant Viruses No 219. Commonw. Mycol. Inst. Kew, Surrey $4 \mathrm{p}$.

Harrison, B. D., Mayo, A. A. \& Baulcombe, D. C. 1987. Virus resistance in transgenec plants that express that express Cucumber mosaic virus satellite R.N.A. Nature 328: 799-802.

Harrison, B. B. \& Murrant, A. F. 1977. Nepovirus group. Commonw. Mycol. Inst. Assoc. Appl. Biol. Descript. of Plant Viruses No 185. C.M.I. Kew, Surrey U.K.

Heikınheımo, O. 1956. Kasviviruksia siirrostavien lehtikirvojen esiintymisestă maassamme. Valt. maatal. koetoim. julk. 178: 20-40.

HUKKıNEN, Y. 1923. Havaintoja herukan äkämäpunkin (Eriophyides ribis Nal) esiintymisestä Suomessa. (Über das Auftreten des Johannisbeeren-Gallmilbe (Eriophyides ribes Nal) in Finland) Agr. Fors. Fin. No 23.

$\mathbf{J}_{\mathrm{ACOB}}, \mathrm{H}$. 1976. Investigation on symptomatology transmission, etiology and host specifity of black currant reversion virus. Acta Horticulturae 66: 99-104.

JAMALAINEN, E. A. 1957. Virus and virus-like diseases in Finland. Valt. maatal. koetoim. julk. 178: 20-40.

Jones, A. T., Murant, A. F. \& Stace-Smith, R. 1977. Raspberry vein chlorosis virus. Commonw. Mycol. Inst. Assoc. Appl. Biol. Descript. of Plant Viruses No 219. Commonw. Mycol. Inst. Kew. Surrey 4pp.

Kallio, T. K., Heikinheimo, O. \& Ryynänen, A. 1980. Terveiden taimien vaikutus mansikan satoon. Koetoiminta ja käytäntö 18. 3. 1980.
KRCAL, H. 1980. Transmission of the strawberry crinkle virus by the strawberry aphid, Chaetosiphon fragaefolii. Acta Phytopathologica Acad. Scient. Hungaricae 15: $97-102$.

Lister, R. M. \& Murant, A. F. 1967. Sap transmission of nematode-borne viruses. Ann. appl. Biol. 54: $167-176$.

Lindroth (LıRo) 1902. Tre för den finska faunen nya Eriophyiden. Acta Soc. Fauna et Flora Fenn. 28: B,1: $3-7$.

MaAs, J. L. (Edit.) 1984. Compendium of strawberry diseases. St. Paul, Minnesota 138 p.

Murant, A. F., Chambers, J. \& Jones, A. T. 1974. Spread of raspberry bushy dwarf virus by pollination, its association with crumbly fruit and problems of control. Ann. Appl. Biol. 77: 221-281.

Murant, A. F. 1976. Raspberry bushy dwarf. Commonw. Mycol. Inst. Appl. Biol. Descript. of plant Viruses No 165. Commonw. Mycol. Inst. Kew, Surrey $4 \mathrm{p}$.

Silvere, A. P. 1970. Mycoplasma-like organisms in association with black currant revision. Resum. X. Congrese Internac. de Microbiol. Mexico 1970.

Stace-Smith, R. \& Jones, 1978. Rubus yellow net virus. Commonw. Mycol. Instit. Assoc. Appl. Biol. Descript. of Plant Viruses No 219. Commonw. Mycol. Instit. Kew, Surrey $4 \mathrm{p}$.

Sylvester, E. S., Frazier, N. W. \& Richardson, J. 1976. Strawberry crinkle virus. Commonw. mycol. Instit. Assoc. Appl. Biol. Descript. of Plant Viruses No 163. Commonw. Mycol. Instit. Kew, Surrey 4p.

TAPIO, E. 1961. Vadelman virustaudit (Virus diseases of raspberry). Valt. maatal. koetoim. julk. No 184.

- 1972. The appearence of soil-borne viruses in Finnish plant nurseries. Maatal.tiet. Aikak. 44: 83-92.

- 1985. The appearance of soil-borne viruses in Finnish plant nurseries II. Maatal.tiet. Aikak. 59: 167-181.

TAYlor, C. E. \& Thomas, P. R. 1968. The association Xiphinema diversicaudatum (Micoletsky) with strawberry latent ringspot and Arabis mosaic viruses in raspberry plantation. Ann. Appl. Biol. 62: 147-157.

Tresh, J. M. 1970. Virus and viruslike diseases of gooseberry and currant. In $n$ Virus diseases of small fruit and grapevines». 290 p. Berkley.

Yearbook Of Farm Statistics 1983. 


\section{SELOSTUS}

\section{Suomessa esiintyvät marjakasvien virustaudit}

\section{Katri Bremer}

Kasvipatologian laitos, Helsingin yliopisto, 00710 Helsinki

Marjan viljelyn laajetessa kahtena viime vuosikymmenenä lisääntyi myös taimien kysyntä. Tăllöin markkinoille pääsi myös heikkolaatuista aineistoa ja marjakasvien tautisuus lisäăntyi. Virustaudit osoittautuivat hankalimmiksi, koska viljelijăllă ei ole mahdollisuuksia niiden torjumiseksi. Tervetaimitoiminnan alettua 1970-luvulla tilanne on parantunut.

Mansikan virustauteja on meillä tutkittu vain văhän. Testaamattomilla taimilla perustetuilla mansikkaviljelmillä noin $12 \%$ kasveista oli viroottisia. Virustaudit mansikassa lienevăt tuontitavaraa, sillä pahimmat saastunnat on todettu ulkomailta tuoduissa kasveissa. Lisäksi mansikan virustautien pahimmat levittäjăt, Chaetosiphonsuvun kirvat eivăt menesty kylmässă ilmastossamme.

Meillä on tavattu taimistoissa monissa kasvilajeissa useita ankeroislevintäisiä, ns. NEPO-viruksia, jotka ovat haitallisia myös mansikalle. Meillă ei ole tietoa niiden esiintymisestä mansikalla.

Vadelman virustautitutkimus on myös rajoittunut virustautitestauksiin ja terveiden taimien tuottamiseen. Kuitenkin on todettu, ettă virustaudit ovat yleisiă sekă viljellyissä että luonnonvaraisissa vadelmissa ja niiden levittäjät iso- (Aphis idaei) ja pieni vattukirva (Amphorophora rubi) esiintyvät yleisinä meillä. Vadelmalle ovat haitallisia myös monet NEPO-virukset. Niiden yleisyyttä vadelmissa ei tunneta.
Virustaudeista puhdistaminen on kannattanut, sillä terveet vadelmat ovat tuottaneet moninkertaisen sadon testaamattomiin taimiin verrattuina usean vuoden ajan.

Herukoissa on meillä todettu useita virustauteja. Kaikki eivăt ole haitallisia. Satoa antavat reversion- eli suonenkatotauti mustaherukalla ja suonikloroosi punaherukalla ja karviaisella. Suonenkatotaudin aiheuttajaa ei tunneta. Tauti leviäă äkämäpunkkien (Cecidophyopsis (Eriophyes) ribis) välityksellä. Tämä äkämäpunkkilaji esiintyy meillä yleisenä.

Suonikloroosi leviaaă useiden kirvalajien vălityksellă. Nămä kirvalajit ovat meillă yleisiả punaherukassa.

NEPO-viruksia on tavattu meillă sekă musta- että punaherukassa, mutta ne eivăt ole olleet haitallisia. Kuitenkin ne saattavat levitä herukoiden mukana uusille viljelyksille.

Marjakasvien virustaudit, etenkin herukan ja mansikan, mutta myös vadelman ovat meillä samoinkuin muuallakin liian vähän tutkittuja. Monien ns. virustautien aiheuttajaa ei tunneta, eräiden leviämistapaa ei tunneta ja kaikille tarvittaisiin tehokkaat testausmenetelmät. Alkanut tervetaimitoiminta tarvitsee sopivia testausmenetelmiä sekä perustietoa taudinaiheuttajista, jonka avulla tautien levinnăn rajoittaminen voidaan toteuttaa. Meillă olisi syytä kiinnittäă erityisesti huomiota maalevintäisten etenkin NEPO-virusten rotulajiston selvittelyyn tehokkaiden testausmenetelmien saamiseksi. 